\title{
Intradural Cement Leakage After Percutaneous Vertebroplasty
}

\section{Perkiutan Vertebroplasti Sonrasinda Intradural Çimento Sizmast}

\author{
Bon-Jour LIN, Chiao-Chu LI, Hsin I MA \\ Tri-Service General Hospital, National Defense Medical Center, Department of Neurologic Surgery, Taipei, Taiwan, R.O.C.
}

Corresponding Author: Hsin I MA / E-mail: i0719andyou0305@hotmail.com

\begin{abstract}
Intradural cement leakage after percutaneous vertebroplasty (PV) is a rare clinical picture. We report a 64-year-old woman with osteoporotic compression fracture of the L2 vertebral body developing monoparesis and monoparesthesia after PV. The diagnosis of intradural cement collection with spinal cord damage was evidenced by clinical and neuroradiographic investigation. After decompressive surgery, the patient showed gradual improvement.

This report highlights the postulated mechanism of intradural cement collection after PV and advocates some intraoperative skills to avoid this complication. In order to get a satisfactory clinical outcome, we suggest early decompressive surgery for those patients having symptomatic intradural cement leakage after PV.
\end{abstract}

KEYWORDS: Intradural, Cement leakage, Vertebroplasty

öz

Perkütan Vertebroplasti (PV) sonrasında intradural çimento sızması nadir bir klinik durumdur. PV sonrasında monoparezi ve monoparestezi gelişen, L2 vertebra cismi osteoporotik kompresyon kırığı bulunan 64 yaşında bir kadın bildiriyoruz. Omurilik hasarıyla intradural çimento toplanması tanısı klinik ve nöroradyografik incelemeyle konmuştur. Dekompresyon cerrahisi sonrasında hasta zamanla iyileşmiştir.

Bu rapor, PV sonrasında intradural çimento birikmesinin düşünülen mekanizmasını açıklamakta ve bu komplikasyondan kaçınmak için bazı intraoperatif işlemleri vurgulamaktadır. PV sonrasında semptomatik intradural çimento sızması olan hastalarda tatminkar bir klinik sonuç elde etmek için erken dekompresyon cerrahisi öneriyoruz.

ANAHTAR SÖZCÜKLER: İntradural, Çimento sızması, Vertebroplasti

\section{INTRODUCTION}

Percutaneous vertebroplasty (PV), cement injection into collapsed vertebral body, is approved as an alternative therapy for painful osteoporotic compression fracture and spinal metastasis. Extravasation of cement is not uncommon among reported complications of PV, and most of them are asymptomatic or clinically insignificant (2). Intradural cement leakage after PV is a rare, and there are only four reported cases up to now. All reported cases developed associated neurological deficit after PV, and a satisfactory clinical outcome was observed only for those accepting appropriate decompressive surgery.

\section{CASE REPORT}

A 64-year-old female, accepting percutaneous vertebroplasty due to osteoporotic compression fracture at L2 vertebral body, complained of weakness and tingling in the left lower limb after the procedure. Neurological examination demonstrated paresthesia distribution below the inguinal region, decreased muscle strength grading $3 / 5$ over left iliopsoas and quadriceps, brisk deep tendon reflex of knee and ankle, grading $3+/ 5+$ with preservation of perineal sensation and anal sphincter tone. Plain radiography of thoraco-lumbar spine showed filling of $L 2$ vertebral body with polymethylmetacrylate (PMMA) and extravasation into spinal canal, especially at the L1 level (Figure 1). Magnetic resonance imaging (MRI) showed an intradural extramedullary mass lesion that was hypointense on T1-weighted images and T2-weighted images. It compressed the spinal cord with displacement and right deviation (Figure 2).

The patient and her family were advised decompressive surgery, L1 and L2 laminectomies with midline durotomy. While opening the dura, PMMA over the dorsal aspect of spinal cord was identified and an irregularly shaped, $3.5 \mathrm{~cm}$ long intradural PMMA was excised smoothly (Figure 3). A few PMMA over the ventral side of spinal cord were left due to adhesion with dura. After surgery, the patient showed obvious improvement of paresthesia. One month later, the patient with a muscle strength grading of $4 / 5$ over the left iliopsoas and quadriceps could walk without assistance. 


\section{DISCUSSION}

Cement leakage after percutaneous vertebroplasty (PV) is not uncommon. It has been reported in between $30 \%$ to $65 \%$ of patients with osteoporosis and between $38 \%$ to $72.5 \%$ of patients with metastatic bone disease (3). The involved areas of cement leakage include the intervertebral foramen, paravertebral soft tissue, epidural space of spinal canal, disc space, lumbar venous plexus, and other areas distant from the operative site such as the pulmonary artery. Most of them are asymptomatic or clinically insignificant, but others could cause a neurological deficit.

Among reported complications of PV, intradural cement leakage is rare. Shapiro et al. reported the first case of intradural extravasation of cement complicating vertebroplasty in 2003
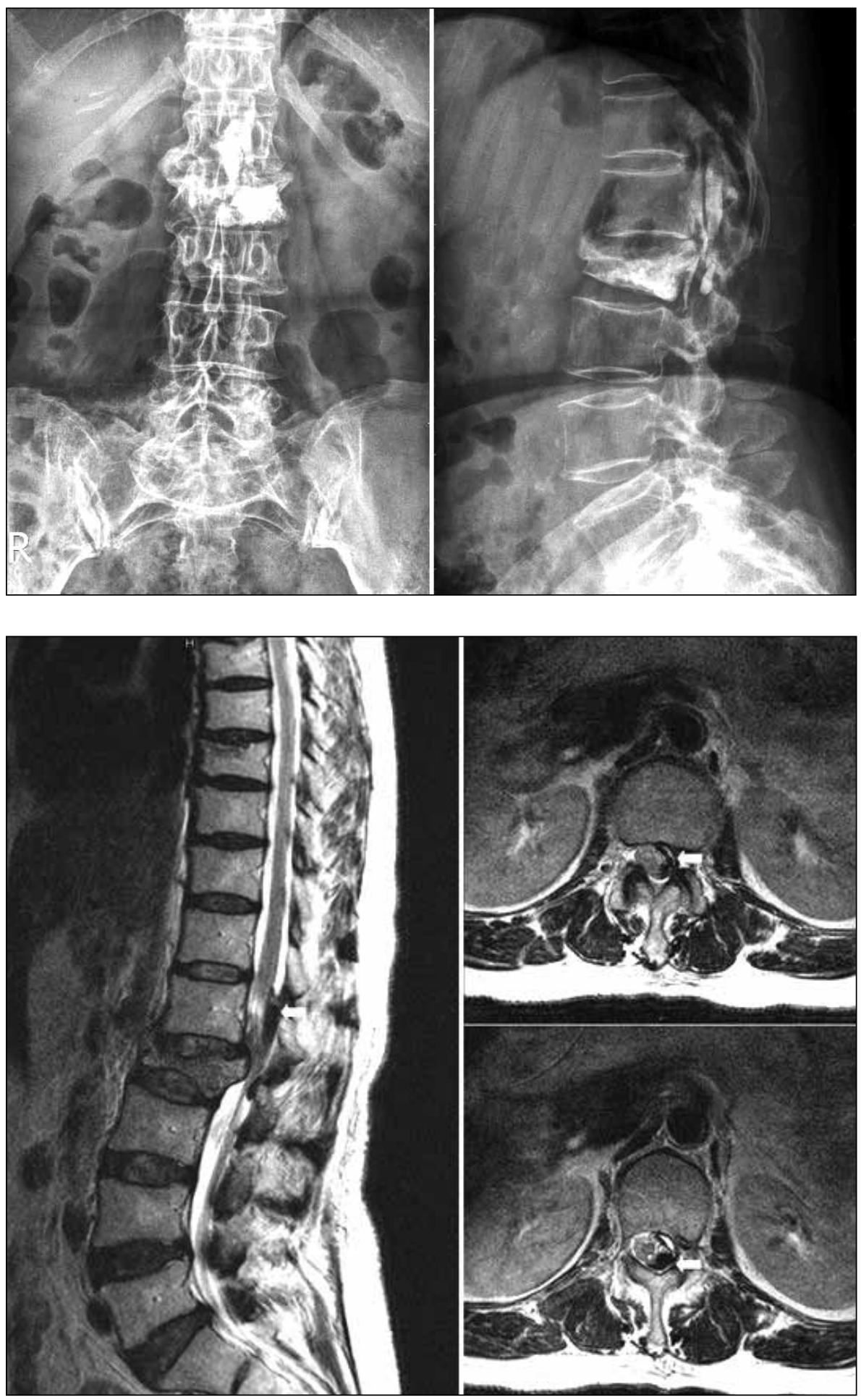

Figure 1: Anteroposterior and lateral radiography of lumbar spine show cement extravasation from the L2 vertebral body into the spinal canal.
Figure 2: Sagittal and axial T2-weighed images reveal one hypointense intradural extramedullary mass lesion (white arrow) causing cord displacement and edema. 


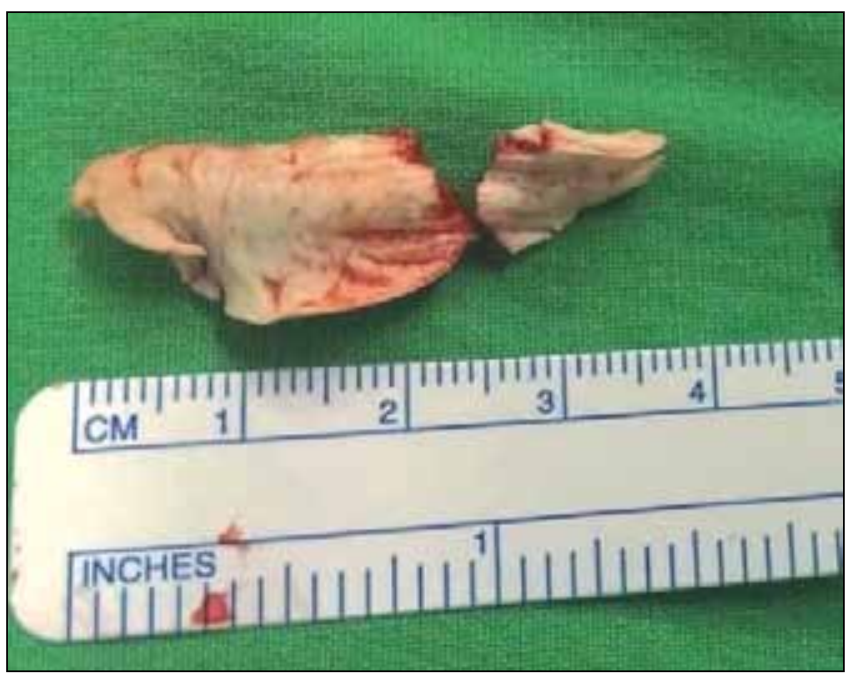

Figure 3: The irregular shaped, $3.5 \mathrm{~cm}$ long intradural PMMA cement collection.

(5). Up to the present time, three others were reported by Chen, Teng, Sabuncuoglu et al repectively and our case is the fifth $(1,4,6)$. The hypothesized mechanism of intradural cement collection is cement extravasation through bony defect, posterior wall of vertebral body or medial wall of pedicle rupture, and dural perforation. This abnormality is attributed to inappropriate surgical technique - deviated direction of needle insertion to the inner side during procedure. To avoid this technical error, it is recommended that the medial border of the pedicle in the antero-posterior view should be the radiographic landmark while the needle tip is arriving at the posterior margin of vertebral body in lateral view. Otherwise, several operative skills could be used to decrease the risk of cement leakage during procedure. Use of cement with glutinous and thicker consistency is recommended to avoid leakage from the vertebral body along the venous tract or cortical bone defect. Otherwise, a well-identified opacity of cement enables immediate monitoring of the distribution by intraoperative C-arm fluoroscopy. Intermittent injection without continuous forceful squeeze is necessary to handle the volume and rate while injecting. Yeom et al. classified cement leakage after PV into three different types according to the postoperative computed tomography (CT) scan (7). They observed that all patients with cement leakage and spinal canal involvement were due to spreading along the epidural venous plexus (basivertebral vein) or cortical bone defect. Thus, the integrity of posterior wall of vertebral body should be assessed by preoperative CT as one part of operative evaluation.

In clinical practice, cement leakage should be suspected in patients developing abrupt onset of uninterpretable symptoms after vertebroplasty. Advanced imaging studies are necessary for diagnosis confirmation and severity evaluation.

Intradural cement leakage could cause a neurological deficit by direct mass effect and thermal injury. It is thought that removal of the leaked cement is difficult and dangerous, and manipulation itself may cause further damage. Among the four reported cases of intradural cement leakage after PV, three patients underwent decompressive surgery. One of them had residual neurological deficit, while the others accepting appropriate decompression experienced neurological improvement after the operation. In our case, there was a satisfactory result after surgery. According to the above findings, early decompressive surgery for patients with symptomatic intradural cement leakage after vertebroplasty is suggested.

\section{CONCLUSION}

We report a rare case of postoperative monoparesis and monoparesthesia after percutaneous vertebroplasty (PV) secondary to intradural cement leakage. Intradural cement leakage is expected inevitably with increased popularity of percutaneous vertebroplasty as an alternative treatment for painful osteoporotic compression fracture or spinal metastasis. It is necessary to keep in mind the direction of needle insertion during the procedure with the medial border of the pedicle in the antero-posterior view as a radiographic landmark and the arrival of the needle tip at the posterior margin of the vertebral body in lateral view to avoid this complication.

We suggest early decompressive surgery as part of therapy planning in order to ensure a better clinical outcome for those with symptomatic intradural cement leakage after PV.

\section{REFERENCES}

1. Chen YJ, Tan TS, Chen WH, Chen CC, Lee TS: Intradural cement leakage: A devastatingly rare complication of vertebroplasty. Spine (Phila Pa 1976) 31:E379-82, 2006

2. Cortet B, Cotten A, Boutry N, Flipo RM, Duquesnoy B, Chastanet $P$, Delcambre $B$ : Percutaneous vertebroplasty in the treatment of osteoporotic vertebral compression fractures: An open prospective study. J Rheumatol 26:2222-2228, 1999

3. Jensen $M$, Evans $A$, Mathis J: Percutaneous polymethylmethacrylate vertebroplasty in the treatment of osteoporotic vertebral body compression fractures: Technical aspects. AJNR Am J Neuroradiol 18:1897-1904, 1997

4. Sabuncuoglu H, Dincer D, Guclu B, Erdogan E, Hatipoglu HG, Ozdogan S, Timurkaynak E: Intradural cement leakage: A rare complication of percutaneous vertebroplasty. Acta Neurochir (Wien) 150:811-815, 2008

5. Shapiro S, Abel T, Purvines S: Surgical removal of epidural and intradural polymethylmethacrylate extravasation complicating percutaneous vertebroplasty for an osteoporotic lumbar compression fracture. Case report. J Neurosurg 98 Suppl 1:9092, 2003

6. Teng MM, Cheng $\mathrm{H}, \mathrm{Ho}$ DM, Chang CY: Intraspinal leakage of bone cement after vertebroplasty: A report of 3 cases. AJNR Am J Neuroradiol 27:224-229, 2006

7. Yeom JS, Kim WJ, Choy WS, Lee CK, Chang BS, Kang JW: Leakage of cement in percutaneous transpedicular vertebroplasty for painful osteoporotic compression fractures. J Bone Joint Surg $\mathrm{Br}$ 85:83-89, 2003 